\title{
Rapid Assessment of COVID-19 Impact on Livestock Sector in Kellem Wollega Oromia Region, Ethiopia
}

\author{
Soresa Shuma Abdisa ${ }^{1, *}$, Abdisa Abraham Challa ${ }^{2}$, Hamba Igazu $^{3}$ \\ ${ }^{1}$ Department of Animal Science, College of Agriculture Veterinary Medicine, Dambi Dollo University, Dembi Dolo, Ethiopia \\ ${ }^{2}$ Department of Natural Resource Management, College of Agriculture Veterinary Medicine, Dambi Dollo University, Dembi Dolo, Ethiopia \\ ${ }^{3}$ Department of Public Health, College of Medicine and Health Science, Dambi Dollo University, Dembi Dolo, Ethiopia
}

\section{Email address:}

soriyeshuma@gmail.com (S. S. Abdisa)

${ }^{*}$ Corresponding author

\section{To cite this article:}

Soresa Shuma Abdisa, Abdisa Abraham Challa, Hamba Igazu. Rapid Assessment of COVID-19 Impact on Livestock Sector in Kellem Wollega Oromia Region, Ethiopia. International Journal of Science, Technology and Society. Vol. 9, No. 4, 2021, pp. 157-161. doi: $10.11648 /$ j.ijsts.20210904.12

Received: June 23, 2021; Accepted: July 19, 2021; Published: July 24, 2021

\begin{abstract}
The COVID-19 general has made a serious negative impact not only for health sector in the country but also all features of living conditions. Subsequently the COVID 19 occurrence began in early Administration has lockdown people's program to control the spread of the disease. To know the present condition of livestock market, Kellem Wollega Zonde has prepared phone call based consultation with 10 entrepreneurs and 50 farmers of 3 districts in the livestock subdivision using organized surveys during September 10-15 2020. Around $90 \%$ would go to nearby hospitals directly if any family member seems to be infected. This figure is alarming and reflected that they only know the disease outbreak but they are not internalizing its pandemic situation. In this situation, Government and other agencies should be concentrated on multipurpose cash support for the COVID-19 affected vulnerable groups, so that they can buy their necessities from their local market for retrieving local economy which will also create an equilibrium condition in market. On the other hand, local administration should increase their strict monitoring for availability of daily necessities in the market and for controlling annoying situations in the market. Subsequently the COVID 19 occurrence began in early March in study area; the Government has lockdown people's movement to control the spread of the disease. Day by day disease affection is increasing geometrically. The lockdowns have had a significant and still not well understood impact on the agricultural sector. According to a recent survey published by BRAC, though the lockdown is useful to prevent the spread of disease as it forces people to stay at home, the average household income falls $70 \%$ caused by sudden shutdown. As all of the livelihood sectors fall into a serious implication, the livestock sector is no exception. The livestock market is also facing continuous loss. Livestock farmers face severe pressure from supply and market disruptions, since animals need to eat every day and production cycles are short daily for dairy and 3-4 months' Cycle for bull fattening.
\end{abstract}

Keywords: COVID-19, Livestock, Lockdown, Impacts

\section{Introduction}

The animal protein intake of an average individual in most African and Pacific countries falls between 8-15 g per day [9], which is far below the 36 grams per day; which is about $55.3 \%$ of the 65 grams per day of protein recommended by FAO [6, 2]. This could partly be as a result of the high cost of finished feeds due to increase in the price of conventional feed ingredients, endemic or pandemic diseases such as
Coronavirus disease-19 (COVID-19) and consequent rise in the cost of animal protein beyond the purchasing power of most people [10]. Feeding is an essential phase in animal production as it takes a significant share of the total costs of intensive animal production schemes [3, 4]. Reported that poultry production is an increasingly important agricultural industry in the world, however, as beneficial and interesting as poultry seems, this sub-sector is set back with high prices of farm input particularly the cost of feed. Any farmer aims to produce a healthy animal and its products at the least cost 
without incurring much money on drugs and be able to get it across to readily available customers. As humans take a dietary supplement daily, so it is the need for animals to enhance their product performance as well as their immunity. [1] stated that animal agriculture takes many forms throughout the United States and worldwide; however, the majority of large animal agriculture is to produce high-quality meat, poultry, dairy products, and eggs. The animal processing industry is a constantly changing, consumer-driven industry that provides billions of dollars and numerous jobs for the economy.

Livestock systems have both positive and negative effects on the natural resource base, public health, social equity, and economic growth [13]. Currently, livestock is one of the fastest-growing agricultural subsectors in developing countries. Its share of agricultural GDP is already 33 percent and is quickly increasing. This growth is driven by the rapidly increasing demand for livestock products; this demand is driven by population growth, urbanization, and increasing incomes in developing countries [5]. On 8 April 2020, the Council of Ministers declared a 5-month long state of emergency in response to the growing number of coronavirus cases. The state of emergency was approved on 10 April by the parliament [8]. Currently; it is spurring dramatic changes to economic, HealthCare, transportation, agricultural production, input supply to agriculture, local and global trade and education systems around the world.

Many national institutions for disease control are obliged to respond to an increasing number of crises instead of focusing on principles of prevention, progressive disease containment, or elimination of a newly emerging disease before it spreads. Consequently, the economic impact of diseases and the cost of control measures are high and becoming higher. Also, sometimes necessary control measures such as isolation may greatly affect the entire production sector and may be devastating for the poorest households for whom livestock forms a major asset. Livestock ownership currently supports and sustains the livelihoods of an estimated 675 million. These people fully or partially depend on livestock for income and/or subsistence. Livestock can provide a steady stream of food and revenues and help to raise whole-farm productivity; livestock is often the only livelihood option available to the landless because they allow the exploitation of common-property resources for private gain. Besides, at the smallholder level, livestock are often the only means of asset accumulation and risk diversification that can prevent a slide into abject poverty by the rural poor in marginal areas. Recent statistics reveal that an estimated $70 \%$ of the poor are women, for whom livestock plays an important role in the improvement of status and represents one of the most important assets and sources of income $[5,11,12]$. Livestock ownership also tends to increase the consumption of animal protein and micronutrients and creates employment opportunities beyond the immediate household.

This review paper attempts a quick summary of the present-day state of animal production systems in the world to the COVID-19 pandemic and how the animal products can be made available in the future or similar occurrences.

\section{Materials and Methods}

\subsection{Description of the Study Area}

Kellem Wollega is one of the 20 zones of Oromia Regional state in Ethiopia. The relative location of the zone can be determined as West Wollega on North and East, Benishangul Gumuz in North-west, Ilubabor zone in South and South-east, Gambella in West and South-west, and Sudan in the West. It extends from $8^{\circ} 10^{\prime} 58^{\prime} \mathrm{N}-9^{\circ} 21^{\prime} 53^{\prime \prime} \mathrm{N}$ latitude and $34^{\circ} 07^{\prime} 37^{\prime \prime} \mathrm{E}-35^{\circ} 26^{\prime} 53^{\prime \prime} \mathrm{E}$ longitude. Its total area is 10488 $\mathrm{km}^{2}$ accounting for about $2.9 \%$ percent of the total area of the Oromia National Regional State.

The highest point in Kellem Wollega is Mount Tulu Walel. The administrative center of this zone is Dembi Dollo. The distance of this Capital is from Addis Ababa is about $652 \mathrm{~km}$. Maize, Sorghum, pulses, and other cereals including coffee have been a major cash crop in Kellem Wollega Zone. The altitude ranges between 500 meters to 1500 meters a.s.1 with three agro-ecological zones $0.2 \%$ of highland climatic zone, $20.35 \%$ middle land and $79.45 \%$ low land climatic zones and annual temperature ranges from $15-25^{\circ} \mathrm{C}$. Whereas the lowest and highest rainfall is $1200-1600 \mathrm{~mm}$, respectively. It has high livestock population consisting of 933,197 cattle, 455,141 sheep, 285,326 goats, 28,787 horse 27,829 mules, 88,495 Donkey and 976,1580 chickens (KWLDFO, 2020).

\subsubsection{Gawo Kebe}

Gawo Kebe is one of the eleven districts in Kellem Wollega Zone. the districts bounded by Babo Gambel districts of West Wollega zone in the north, Kondala districts of West Wollega zone in the North west, Jima Horro districts in the West, and Yemalogi Walal districts in the south, Dale Wabara in the east and Ayra districts of West Wollega zone in the north east. Astronomically, location of the districts is found on next longitude and latitude taken from four directions. On the North west it is found on the $\left(34^{\circ} 45^{\prime} 52^{\prime \prime} \mathrm{E}\right.$, $\left.9^{\circ} 15: 23 \mathrm{~N}\right)$, on the North East it is found on $\left(35^{\circ} 00: 20^{\prime \prime} \mathrm{E}\right.$, $\left.9^{\circ} 15: 23 \mathrm{~N}\right)$, on the South West it is found on $\left(34^{\circ} 45: 42 \mathrm{E}\right.$, $\left.9^{\circ} 00 ; 55 \mathrm{~N}\right)$ and $\mathrm{On}$ the South East it is found on $\left(35^{\circ} 00,20 \mathrm{E}\right.$, $\left.9^{\circ} 00,35 \mathrm{~N}\right)$ approximately. The altitude ranges between $1300-$ 3303 meters above sea level with three agro-ecological zones: It constitute highland (13.3\%), middle land (46.7\%) and low land (40\%) agro climatic conditions. It is located at about 86 $\mathrm{km}$ Kellem Wollega zonal town Dembi Dollo and is about $594 \mathrm{~km}$ from Addis Ababa. The lowest and highest annual average temperature is $11^{\circ} \mathrm{C}$ and $25^{\circ} \mathrm{C}$, respectively. The mean annual rainfall is $1700 \mathrm{~mm}$ whereas the lowest and highest rainfall is $1200 \mathrm{~mm}$ and $2200 \mathrm{~mm}$, respectively (GKDAO, 2015). The area has 65,678.05 hectare of land and out of these about $18.61 \%$ is under grazing land, $50.39 \%$ is cultivable land and the rest $31 \%$ is covered with forest, swampy, mountains, marshy, valley, gorges, construction and degraded land. Gawokebe will be selected by considering its high indigenous goat population as it is first largest from all 11 districts and accessibility. The area has 86,186 goats, 194,120 cattle, 13,396 donkeys, 59,741 sheep, 2122 mules, 102 horses, 137,396 poultry (GKDAO, 2015). 


\subsubsection{Jimma Horro}

This district is bounded by Begi district in North, Gawo Kebe district in East, Yamalogi Wolel district in South and Gidami district in West. The area is located at about $665 \mathrm{~km}$ west of Addis Ababa. The area is located at an elevation of $1400-1830 \mathrm{~m}$ above sea level. The Topography of this district is characterized by Forest of Wolel Mountain and Dati Wolel Park. The main river in this district is Supe, Burar and Kumbabe. The climatic condition alternates with long summer rain fall (June to September), short rainy season (March to May) and winter dry season (December to February). The minimum and maximum annual rain fall and daily temperature range from 800 to $1200 \mathrm{~mm}$ and 15 to $25 \mathrm{o} \mathrm{c}$, respectively. Jimma Horro district is characterized by Dega (19.7\%), Woyna dega (48.5\%) and Kola (31.8\%). Livestock population in area is estimated to be about 91671 heads of cattle, 300 mules, 12500 donkeys, 7225 Horses 26650 sheep, 20166 goats and 98271 species of poultry. The farmers in the area practice mixed farming.

\subsection{Research Methodology}

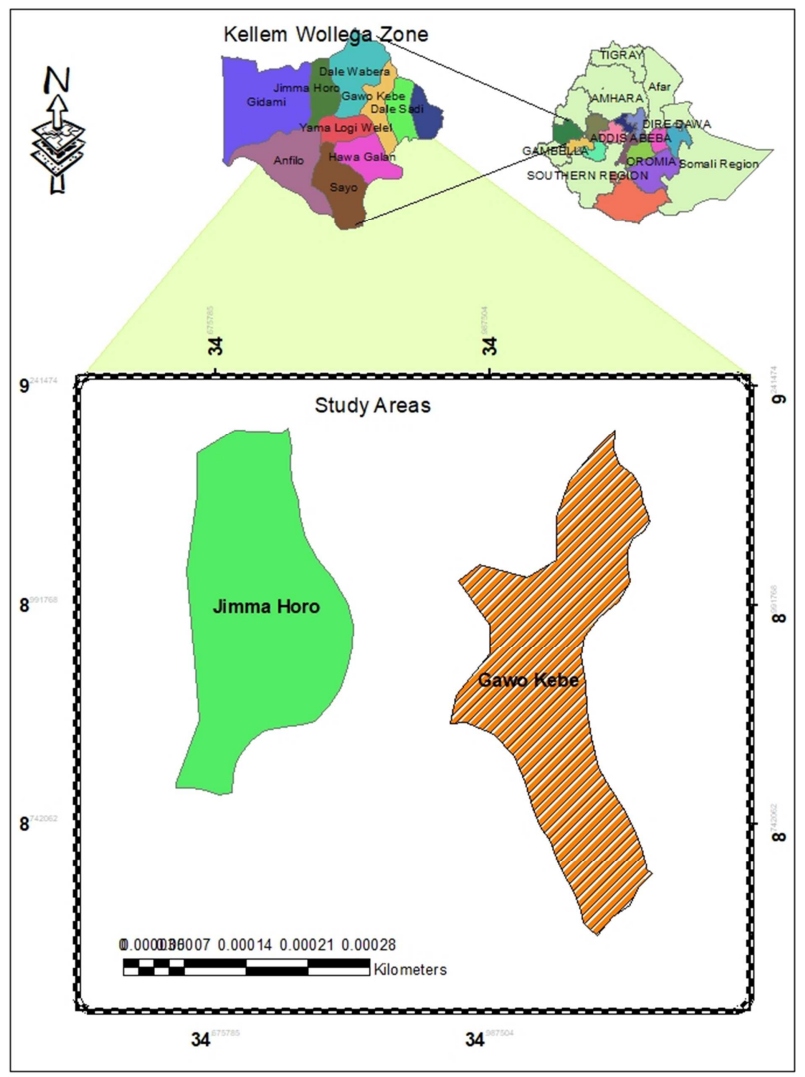

Figure 1. Map of Study area.

The study has employed both quantitative and qualitative methods to assess the COVID 19 impact on livestock sector. Data has collected through the phone call survey with 10 entrepreneurs and 50 livestock farmers using structured questionnaires during 10-15 September 2020. Besides, study has analyzed different print and electronic media reports to understand the sector as a whole. Household heads or persons who take major decisions for farming and or business were consulted to understand business performance, market behavior, COVID 19 awareness, gender issues and current priority of their livelihood and business expansion.

\section{Result}

\subsection{Livestock Markets Scuffle Under COVID 19 Limitations}

Livestock markets struggle under COVID 19 restrictions the pandemic has reduced input demand, cutting income of business on which thousands of entrepreneurs and producers depend for their livelihoods. The below chart shows sales of $40 \%$ retailers and income of $35 \%$ privets, $30 \%$ farmers are reduced compared with the normal market.

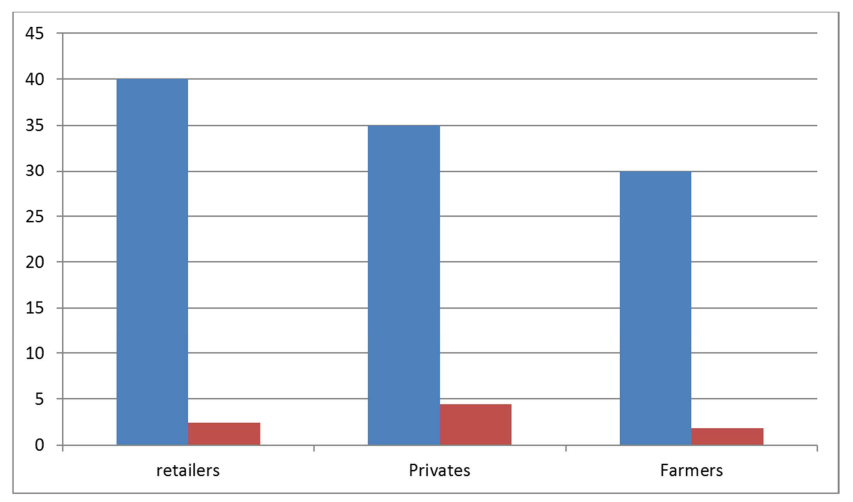

Figure 2. Covid19 impact on livestock markets.

The average daily customers and sales of $40 \%$ retailers are reduced by $20 \%$ and $17 \%$ compared to the scenario before COVID-19 respectively. The daily customers dropped to 40 from 50 around $37 \%$ retailers reported that they cannot collect their input on time due to restricted transportation and limited supply from companies. About $40 \%$ entrepreneurs forecasted that they will face huge losses, if the situation continues for next 4 months. Livestock farmers also face severe pressure from supply and market disruptions. COVID19 impact at household level almost all respondents (50\%) reported that their household income has reduced significantly and $45 \%$ reported increased expenditure at their household. The study findings depicted that $75 \%$ surveyed households used their savings and $25 \%$ took loans for managing households' expenditure. Around 15\% respondents reported that household members lose their job or opportunity to earn due to coronavirus outbreak.

\subsection{COVID-19 Awareness}

All respondents know about coronavirus disease outbreak through the social, print and electronic media, mobile network as well as government messaging. About $70 \%$ respondents are connected with different media to be informed and about $95 \%$ respondents took preventive measures of their own as they said that they are frequently washing their hands using soap, maintaining social distance etc. Respondents were asked, what measure they would take if any family member seems to be infected. Around $90 \%$ 
would go to nearby hospitals directly which is alarming and reflect that they only know the disease outbreak but they are not internalize its pandemic situation.

\subsection{Demographic Profile of Survey Respondent}

The study analysis based on $86 \%$ male and $14 \%$ female consultation. Education plays great role in transferring technology to farmers and to initiate their willingness to adopt technologies. Higher percentages of respondents in the study areas were educated (elementary to high school and college) and While only $23.6 \%$ were illiterate. The presence of educated farmers in the study area could be an opportunity in awareness of COVID 19 privations.

\subsection{Impacts of the COVID-19 C on Livestock Production}

According to [7], the livestock sector has been affected more than 56 per cent by COVID-19 compared to sectors like tourism, construction and transport. In livestock, there might be an income shock, if import and distribution of necessary inputs the planting season (especially fertilisers) is disrupted. Other drivers of shocks in livestock are potential decline exports of key cash crops such as meat and sesame and decline in the local production of poultry and egg due to compound feed supply limitations in the study areas. The result also indicated that more than 25 per cent of sample farmers in the study areas are advised to stay at home and about 19 per cent of them were impacted on selling from produce and business firms are lying off their workers. As a result, more than 25 per cent (Table 1) of the sample household in the study areas were impacted on daily wages since laborer is also reducing their effort with many forced layoff days. Although the impact of the pandemic on economic activities may differ, almost all sectors and subsectors are expected to be negatively impacted by the COVID-19 layoff effects, on the one hand, and workers who lose their jobs spend less, on the other [3].

Table 1. Impacts of the COVID-19 C on Livestock in the Study Areas.

\begin{tabular}{lll}
\hline Variable & Category/Response & Percentage \\
\hline COVID-19 Impact on livelihood & Impact on selling farm produce & 19 \\
& Impact on daily wages laborers & 25 \\
& Impact on livestock & 56 \\
\hline
\end{tabular}

Source: Survey result, 2020.

\subsection{Preventive Measures Taken by the Smallholder Farmer Against the COVID-19}

In the study areas, more than 50 per cent sample households were informing workers on preventive measures against the COVID-19, particularly on transmission and prevention of the virus during the period of production. According to Table 2, efforts taken by the smallholder farmer to contain the spread of the disease through the period of production were stay at home (11.2\%), social distancing (14.8\%), informing workers on COVID-19 transmission and prevention (51.8\%) and providing personal protection equipment like masks (13.3\%) are strong measurement taken by the smallholder farmer in order to fight COVID-19. In addition, firms that rely on supply chains may be unable to get the required inputs, from the nearest market. It is also important to note that restrictions on the movements of people will interrupt several value chains, availability of food and agricultural products, with a potential impact on prices. These disruptions contribute to a rise in business costs and constitute a negative productivity shock, thereby reducing economic activity.

Table 2. Preventive Measures Against the COVID-19 in the Study Areas.

\begin{tabular}{lll}
\hline Variable & Category/Response \\
\hline Preventive measures against the COVID-19 & Informing workers on COVID-19 transmission and prevention \\
& Encouraging workers to stay at home when they feel sick \\
& Physical distancing between workers or staggered/shift work \\
& Frequent/daily temperature checks & 11.2 \\
14.8 & Providing personal protection equipment like masks \\
\hline
\end{tabular}

Source: Survey result, 2020.

\section{Conclusion}

As the global population decreases due to the Covid-19 pandemic and possible hunger in most developing countries of the world, it is noteworthy to say animal products suffer consumption as an average individual just wants to survive without considering the nutritional requirement of the body system for functionality and production. Animals suffer a great deal due to restrictions on the movement of personnel, availability of feed ingredients/ materials, drugs, and vaccines which are very vital in animal production. Farmers are making a lesser profit due to reduced consumption of different animal products; the paying of farmworkers is paramount and important in farm growth.

The whole world is now almost paralyzed by coronavirus. It goes without saying that the big devastation is coming in the economy. If this situation is sustained, food crisis will start in the country. The most pressing need at the moment is in the agricultural sector including livestock sector 


\section{Recommendations}

1) Government should Support in input provision (feed/medicine/vaccine) for cattle of livestock rearing households to encourage the farmers for continuing with this current livestock farming.

2) Interest free or flexible repayment based long term credit facilities should be ensured for agro-based enterprises to revive from the severe shocks of COVID-19 and to run their current business.

3) Mass awareness should be continued through electronic and print media as well as using other social media and communication platforms for internalizing COVID 19 pandemic. In some time, administration should be strict for implementing the government rules.

4) Government and other agencies should be concentrated on multipurpose cash support for the COVID-19 affected vulnerable groups, so that they can buy their necessities from their local market for retrieving local economy which will also create an equilibrium condition in market. On the other hand, local administration should increase their strict monitoring for availability of daily necessities in the market and for controlling annoying situations in the market.

\section{Declaration of Conflicting Interests}

The authors declare that they have no competing interests.

\section{Acknowledgements}

The authors would like to thank for Dambi Dollo University to support for grant funding to this research. The second also thank for all data collectors and farmer's informants in the study areas really, deserve special acknowledgement for their cooperation and willingness to answer the interview questions and share a rewarding experience for support to conduct research and writing this article.

\section{References}

[1] Adeniran, A. O., Akanbi, O. M. and Sidiq, O. B. (2019): Strategy for Agricultural Intensification in Nigeria: Emphasis on Agricultural Aviation. International Educational Scientific Research Journal. 5 (6): 32-36.
[2] Akanbi, O. M. (2019): Performance and health implication of feeding fungi treated cocoa pod husk meal on broiler. Bulletin of the National Research Centre. 43 (55): 1-8.

[3] Akanbi, O. M., Aigbogun, G. O. and Oluponna, J. A. (2020): Effect of ginger (Zingiber officinale) and garlic (Allium sativa) on the performance, haematology and serum biochemical indices of laying hens. Anaesthesia and Surgery Open Access Journal. 1 (3): 1-5.

[4] Asghar, A., Farooq, M., Mian, M. A. and Khurshid, A. (2000): Economics of Broiler Production of Mardan division. Journal of Agriculture and Rural Development 32 (3): 56-65.

[5] Delgado, C. (2005): Rising demand for meat and milk in developing countries: implications for grasslands-based livestock production. In Grassland: a global resource (ed. D. A McGilloway), pp. 29-39. The Netherlands: Wageningen Academic Publishers.

[6] FAO. (2008): The state of food and agriculture. FAOSTAT Production database. Food and Agriculture Organization of the United Nation, Rome.

[7] Geda, A. 2020. The Macroeconomic and Social Impact of COVID-19 in Ethiopia and Iannotti, L. L., et al. "Eggs in Early Complementary Feeding and Child Growth: A Randomized Controlled Trial," Pediatrics, (June 2017).

[8] ILO. 2020. COVID-19 and World of Work: Impacts and Responses. Geneva: ILO. in Sub-Saharan Africa an Analysis of Issues Shaping Africa's Economic Future'. New York: The Free Press.

[9] Ogunsipe, M. H., Balogun, K. B., Oladepo, A. D., Ayoola, M. A. and Arikewuyo, M. T. (2017): Nutritive value of cocoa bean shell meal and its effect on growth and haematology of weaning rabbits. Nigerian Journal of Agricultural Food Environment. 13 (1): 23-28.

[10] Oloruntola, O. D., Agbede, J. O., Onibi, G. E. and Igbasan, F. A. (2016): Replacement value of rumen liquor fermented cassava peels for maize in growing rabbit diet. Archivos de Zootechnica. 65 (249): 89-97.

[11] Perry, B. D. and Grace, D. (2009): The impacts of livestock diseases and their control on growth and development processes that are pro-poor. Phil. Trans. R. Soc. B (2009) 364, 2643-2655. (DOI: 10.1098/rstb.2009.0097)

[12] Thornton, P. K (2010): Livestock production: recent trends, future prospects. Phil. Trans. R. Soc. B (2010) 365, 28532867 (DOI: 10.1098/rstb.2010.0134).

[13] World Bank Group (2019): Pandemic Preparedness Financing - Status update, World Bank, September 2019. 